Boise State University

ScholarWorks

7-1-2012

Morphology and Phylogeny of a New Woodruffiid Ciliate, Etoschophrya inornata sp. n. (Ciliophora, Colpodea, Platyophryida), with an Account on Evolution of Platyophryids

William A. Bourland

Boise State University

Greg Hampikian

Boise State University

Peter Vd'ačný

Comenius University 


\title{
Morphology and Phylogeny of a New Woodruffiid Ciliate, Etoschophrya inornata sp. n. (Ciliophora, Colpodea, Platyophryida), with an Account on Evolution of Platyophryids
}

\author{
William A. Bourland and Greg Hampikian \\ Boise State University
}

\author{
Peter Vd'ačný \\ Comenius University
}

\begin{abstract}
We studied the morphology, morphometry, resting cysts, and molecular phylogeny of a new woodruffiid ciliate, Etoschophrya inornata, from ephemeral puddles and two lacustrine habitats in Idaho, Northwest U.S.A. Up to now the genus Etoschophrya has included a single species, E. oscillatoriophaga, from which our new form is distinguished by (1) the absence of interkinetal cortical granules and, consequently, the absence of extrusible red material in methyl green-pyronin stains; (2) usually $\geq$ five adoral membranelles vs. usually four; (3) greater length and length:width ratio; (4) prominent cortical furrows vs. inconspicuous; and (5) adaptation to nonsaline semiterrestrial and lacustrine habitats in the Nearctic vs. highly saline alkaline Afrotropic soil habitats. Resting cysts have two distinct membranes and a thick hyaline mucous pericyst layer. However, only one membrane persists in older cysts. Like its congener, E. inornata feeds exclusively on filamentous cyanobacteria. The 18S rRNA gene sequence places this species in a strongly supported clade with Kuklikophrya ougandae basal to the other platyophryids. We include a morphologic cladistic analysis of platyophryid ciliates and present a hypothetical scenario for the evolution of the platyophryid oral structures.
\end{abstract}

\section{Introduction}

Colpodean ciliates of the family Woodruffiidae Gelei, 1954 are mainly terrestrial and semiterrestrial predators or bacterivores. At the time of Foissner's (1993) seminal monograph of the Colpodea, the family Woodruffiidae was comprised of five genera, Rostrophryides, Woodruffia, Woodruffides, Rostrophrya and Kuklikophrya. Only the monotypic genus, Etoschophrya, has been added since by Foissner et al. (2002). Etoschophrya oscillatoriophaga Foissner et al., 2002, was discovered at only two out of 73 carefully studied sites in Namibia, Southwest Africa (Foissner et al. 2002). The soil of both sites was alkaline and highly saline. As the species name implies, this ciliate feeds exclusively on filamentous cyanobacteria. We were surprised to find a new species assignable to Etoschophrya in neutral non-saline puddles and freshwater ponds in Idaho, Northwest U.S.A. In this report we describe the morphology, morphometry and 18S rRNA gene sequence of this new species and include a morphology-based cladistic analysis and a hypothetical schema for the evolution of the platyophryid ciliates based on a synthesis of our molecular and morphological analyses.

\section{Material and methods}

\section{Collection data}

Etoschophrya inornata sp. n., Kuklikophrya ougandae (Dragesco, 1972) Foissner, 1993 and Woodruffides metabolicus (Johnson \& Larson, 1938) Foissner, 1987a were found in 2 to $5 \mathrm{~cm}$ deep ephemeral puddles at the margins of a grass sports field in Boise, Idaho, Northwest U.S.A. from May through November 2010. A detailed description of the site is given in the "Occurrence and ecology" section. Foissner (1987a) transferred Woodruffia metabolica Johnson \& Larson, 1938 to the genus Woodruffides as W. metabolica on the basis of its platyophryid silverline pattern. The species name was subsequently corrected to W. metabolicus to agree with the masculine gender of the genus name (Foissner 1993). Bromeliothrix metopoides Foissner, 2010 was collected from the tank of a small cultivated terrestrial bromeliad on the grounds of the Instituto de Biologia, Universidade Federal do Rio de Janeiro, Ilha do Fundão, Rio de Janeiro, Brazil. Raw samples were maintained for up to one week at room temperature $\left(20-24^{\circ} \mathrm{C}\right)$. Attempts to establish pure cultures of $E$. inornata sp. n. were unsuccessful. 


\section{Morphologic methods}

Live ciliates and resting cysts of Etoschophrya inornata sp. n. were studied at magnifications of 40-1,000 $\times$ with brightfield, phase and differential interference contrast (DIC) using a Zeiss Axioskop 2 plus microscope. Impregnations including protargol (Wilbert modification), silver carbonate, Klein-Foissner silver nitrate and the Chatton-Lwoff silver nitrate method were carried out as described by Foissner (1991). Counts of adoral membranelles and paroral membrane dikinetids were taken only from silver carbonate preparations, as in the description of E. oscillatoriophaga (Foissner et al. 2002), since these features are often obscured in Chatton-Lwoff silver nitrate preparations. Although the details of the infraciliature are best shown in temporary silver carbonate preparations, our permanent silver carbonate impregnations were of poor quality. Our Chatton-Lwoff silver nitrate impregnations bleached badly after several weeks, a problem also experienced with E. oscillatoriophaga by Foissner et al. (2002).

Methyl green-pyronin (Waldeck, Münster, DE) staining was done according to Foissner (1991). Formation of resting cysts was induced by isolating free-swimming cells on slides in a moistened chamber in filtered site water without food. Cells were examined during the first several hours of isolation and then at 24-hour intervals over three weeks. Kuklikophrya ougandae and Woodruffides metabolicus were identified from live observations, silver impregnation and examination of resting and division cysts using data from Dragesco \& Dragesco-Kernéis (1986), Foissner (1993) and Foissner et al. (2002). Bromeliothrix metopoides was identified based on the description by Foissner (2010) and the partial 18S rRNA gene sequence obtained by Dunthorn et al. (2008; mentioned as chainforming colpodid ciliate with GenBank Accession No. AY398684). However, in phylogenetic analyses, our new longer sequence of this species has been used. A Flex digital camera and calibrated Spot imaging software (Diagnostic Instruments, Inc.) were used for microphotography and measurements. In vivo measurements were made from microphotographs of uncompressed cells. Image post-processing was done with Adobe ${ }^{\circledR}$ Photoshop CS4. Statistical analyses were performed using MedCalc for Windows, version 11.2 (MedCalc Software, Mariakerke, Belgium). Soil conductivity measurements were done on aqueous extractions $\left(\mathrm{EC}_{1: 5}\right)$ using an ExStik (TM) EC meter (Spectrum Technologies, Inc. Plainfield, Illinois). Extrapolation to values for saturated soil pastes $\left(\mathrm{EC}_{\mathrm{se}}\right.$ ) was done according to Armstrong (2009). Drawings were based on microphotographs.

\section{DNA extraction, amplification and sequencing}

Cells were selected from samples using micropipettes, washed three times in sterile distilled water and collected in $10 \mathrm{mM}$ Tris-Cl buffer ( $\mathrm{pH}$ 8.5) and stored at $-20{ }^{\circ} \mathrm{C}$. DNA was extracted from 10-20 cells using a modified Chelex method (Strüder-Kypke \& Lynn 2003). PCR was done as follows: in 0.2-ml PCR tubes, we used $12.5 \mu 1$ HotStar Master Mix (Qiagen), universal eukaryotic forward primer, EUK-A 5'-AACCTGGTTGATCCTGCCAGT-3' (Medlin et al. 1988) and reverse primer EUK-B 5'-TGATCCTGCAGGTTCACCTAC-3' (Medlin et al. 1988) both in a final concentration of $0.4 \mu \mathrm{M}, 5 \mu \mathrm{l}$ of the Chelex extraction and sufficient distilled water for a volume of $25 \mu \mathrm{l}$. PCR was done in the MJ Mini (Bio-Rad) thermocycler with the following program: $95{ }^{\circ} \mathrm{C}$ for 2 min $30 \mathrm{~s}, 35$ identical amplification cycles $\left(95^{\circ} \mathrm{C}\right.$ for $30 \mathrm{~s}, 58{ }^{\circ} \mathrm{C}$ for $20 \mathrm{~s}, 65^{\circ} \mathrm{C}$ for $\left.2 \mathrm{~min} 30 \mathrm{~s}\right), 65^{\circ} \mathrm{C}$ for $5 \mathrm{~min}$, and indefinite hold at $4{ }^{\circ} \mathrm{C}$. PCR products were checked by $1 \%[\mathrm{w} / \mathrm{v}]$ agarose gel electrophoresis and then purified (Qiaquick PCR Purification Kit, Qiagen). DNA sequencing in both directions was done at the Sequetech facility using the ABI 3730xl DNA Analyzer and BigDye Terminator methodology (Sequetech Corp., Mountainview, California). Both amplification primers and internal primers 690R 5'-AGAATTTCACCTCTG-3' (Hoeck et al. 1998), 1280F 5'TTAGTTGGTGTGCATGGCCGTTC-3' (Wylezich et al. 2002), 998R 5'-GACGGTATCTAATCGTCTTT-3' (designated 1147R with sequence 5'-GACGGTATCTR-ATCGTCTTT-3' by Dopheide et al. 2008), 1545R 5'GGAATTCCTCGTTCAAGATC-3' (Bourland et al. 2011) were used to sequence the 18S rRNA gene. Chromatograms were manually edited using 4-Peaks (Griekspoor \& Groothuis 2006) and assembled into contiguous sequences using CAP3 (Huang \& Madan 1999).

\section{Phylogenetic analyses}

To determine the phylogenetic position of Etoschophrya inornata sp. n. within the class Colpodea, we analyzed an alignment containing 18S rRNA gene sequences from all major colpodean lineages. Two nassophorean ciliates (Obertrumia georgiana and Furgasonia blochmanni) were chosen as an outgroup. All sequences, except for those obtained in this study, were retrieved from GenBank (Table 1). Alignments were constructed using MAFFT (Katoh $\&$ Toh 2008) based on primary structure. Ambiguously aligned regions were masked using gBlocks v0.91b with the 
option to allow smaller final blocks (Castresana 2000; Talavera \& Castresana 2007). One alignment consisted of 32 taxa and 1596 nucleotide characters. Modeltest 3.7 (Posada \& Crandall 1998) was employed to find the model of nucleotide substitution that best fit the data. The General-Time-Reversible model with invariable sites and gamma distribution $(\mathrm{G}+\mathrm{I}+\Gamma)$ was chosen under the Akaike Information (AI) Criterion. This model was implemented in MrBayes (Ronquist \& Huelsenbeck 2003) on the CIPRES Portal V 1.15 (Miller et al. 2009), with support from six simultaneous MCMC chains run for 5 million generations sampling every 1000 generations. The first $25 \%$ of sampled trees were considered burn-in trees and were discarded prior to tree reconstruction. A $50 \%$ majority rule consensus of the remaining trees was used to calculate posterior probability (PP) for Bayesian inference (BI). The maximum likelihood (ML) analysis was implemented on the CIPRES Portal, using RAxML with settings as described in Stamatakis et al. (2008). The maximum parsimony (MP) and neighbor-joining (NJ) analyses were carried out in PAUP* ver. 4.0b8 with randomly added species and tree bisection-reconnection (TBR) branchswapping algorithm in effect (Swofford 2001). A neighbour-joining (NJ) tree was constructed in ML distance with the $\mathrm{G}+\mathrm{I}+\Gamma$ substitution model as suggested by Modeltest. Support for ML, MP and NJ analyses came from 1000 bootstrap replicates using heuristic searches.

We also carried out two additional alignments, one as described above (i.e., two nassophorean taxa as outgroup) but excluding the order Colpodida and another excluding the Colpodida but with the Cyrtolophosodida sensu Foissner $e t$ al. (2011) as the outgroup. These alignments included 17 taxa and 1627 nucleotide characters and 15 taxa and 1623 nucleotide characters, respectively. The phylogenetic analyses were performed as described above except using the $\mathrm{TrN}+\mathrm{I}+\mathrm{G}$ and $\mathrm{TIM}+\mathrm{I}+\mathrm{G}$ substitution models, respectively (selected in Modeltest using the AI Criterion).

\section{Tests of phylogenetic scenarios}

Constrained analyses were carried out on the first 18S rRNA gene alignment created for the genealogical studies as described above. Using ML criterion and a heuristic search with tree bisection reconnection (TBR) swapping algorithm and 10 random sequence addition replicates, eight trees with enforced topological constraints, in addition to the best ML tree, were built in PAUP* (Table 3). To compare the resulting constrained topologies with the best non-constrained topology, the site-wise likelihoods for all trees were calculated in PAUP* under the GTR $+\mathrm{I}+\Gamma$ model with the following parameter values selected by Modeltest under the AI Criterion: gamma distribution shape parameter $\Gamma=0.5670$; proportion of invariable sites $\mathrm{I}=0.5980$; base frequencies $\mathrm{A}=0.2815, \mathrm{C}=0.1896, \mathrm{G}=$ $0.2563, \mathrm{~T}=0.2726$; and rate matrix for the substitution model $[\mathrm{AC}]=0.7421,[\mathrm{AG}]=2.9898,[\mathrm{AT}]=1.4431$, $[\mathrm{CG}]$ $=0.6413,[\mathrm{CT}]=6.4872$, and $[\mathrm{GT}]=1.0000$. The reliability of the constrained trees was analyzed in likelihood frameworks through the approximately unbiased test (AU), the weighted Shimodaira-Hasegawa test (WSH), and the weighted Kishino-Hasegawa test (WKH) implemented in the CONSEL software package (Shimodaira \& Hasagewa 2001).

\section{Cladistic analyses}

Morphological evolution within the order Platyophryida was analyzed using the computer program PAUP* ver. 4.0b8. The genera Cyrtolophosis and Pseudocyrtolophosis, belonging to the order Cyrtolophosidida, were chosen as the outgroup because they are morphologically nearest to the platyophryids but cluster outside the platyophryid clade in molecular phylogenies. The cladistic analyses are based on five groups of diagnostic and phylogenetically informative characters in the platyophryids: the body shape (character 1), the morphology of the oral apparatus (characters 2-10), the silverline pattern (character 11), the specialities of the nuclear apparatus (character 12), and the formation of a sorocarp during the life cycle (character 13). As concerns the polymorphic character 5 (number of adoral organelles), the "majority rule" was applied which codes a polymorphic genus as having the trait that is most common among its species (Wiens 2000). All data were obtained from the original descriptions or authoritative redescriptions of the platyophryids (Njiné 1979; Puytorac et al. 1979, 1992; Bradbury \& Olive 1980; Foissner 1980, 1987a, 1993; Dragesco \& Dragesco-Kernéis 1986; Wilbert \& Kahan 1986; Bardele et al. 1991; Foissner et al. 2002). The following features were not included in the cladistic approach because they are known only in a small portion of the genera/species: ontogenetic peculiarities and resting as well as reproductive cyst characteristics. The characters and character states are summarized in Table 4, and their distribution is given in Table 5.

The cladogram was computed in a MP framework with ordered states in the characters 1 and 2. Weight In the first set of analyses, all characters had weight 1 . However, this approach resulted in a basal polytomy of the order Platyophryida. Thus, in the next step, weight 3 was assigned to the characters 3,6 and 12, as they seem to be of a 
high phylogenetic importance according to the molecular phylogenies. The remaining characters had weight 1 . This analysis brought a much better resolved cladogram. Therefore, we performed two further analyses, using weight 5 and then 10 for the same three characters as mentioned above. In comparison with the first weighted analysis the resolution was slightly improved, but there was no difference between the two latter analyses. Thus, we refer only to the cladogram which was obtained with weight 5 for the characters 3,6 and 12 in the Results and Discussion.

The reliability of internal branches in the MP cladogram was assessed using the bootstrap method with heuristic search including 100 replicates. Further, Bayesian inference analyses were performed in which nodal support came from posterior probabilities, using one million generations and trees sampled every 1000 generations.

\section{Terminology}

Terminology is according to Foissner (1993), Foissner \& Xu (2007), Foissner et al. (2002), Grain et al. (1979), and Lynn (2008). We follow the ordinal-level structure for classification of Colpodea proposed by Foissner et al. (2011).

\section{Results}

\section{Description of Etoschophrya inornata sp. n. (Figs 1-4; Table 2)}

Class Colpodea Small \& Lynn, 1981

Order Platyophryida Puytorac et al., 1979

Family Woodruffiidae Gelei, 1954

Genus Etoschophrya Foissner et al., 2002

Etoschophrya inornata sp. n.

Holotype. The slide containing the holotype specimen (Fig. 3B, C) has been deposited in the Biologiezentrum of the Oberösterreichische Landesmuseum in Linz (LI), Austria. Relevant specimens are marked with ink circles on the coverslip.

Paratypes. Three paratype slides of Chatton-Lwoff silver nitrate specimens (reimpregnated after bleaching), collected from the type locality in Boise, Idaho, U.S.A., have been deposited in the Biologiezentrum of the Oberösterreichische Landesmuseum in Linz (LI), Austria. These reimpregnated preparations are of sufficient quality to reveal the silverline pattern. Relevant specimens are marked with ink circles on the coverslip.

Voucher material. The 18S rRNA gene nucleotide sequence of Etoschophrya inornata sp. n., collected from the type locality, is available in GenBank (http://www.ncbi.nlm.nih.gov/nucleotide/) with accession number XX123457.

Etymology. From the Latin adjective inornat.us, - a, -um [m, f, n] meaning "unadorned" in reference to the absence of interkinetal cortical granules.

Diagnosis. Size about $55 \times 30 \mu \mathrm{m}$ in vivo. Body shape slender obovate. On average 22 leftward spiraling somatic kineties, 5 adoral organelles and 28 paroral dikinetids. Cortex prominently furrowed, without interkinetal granules. Resting cyst spherical with two distinct layers and outer mucous coat.

Type locality. Ephemeral freshwater puddles at the margin of a grass sports field at Fort Boise Park in Boise, Idaho, U.S.A. N4336'52.33” W116¹1'21.75” elev. $832 \mathrm{~m}$.

Description (type population). Size 47-60 $\times 21-37 \mu \mathrm{m}$ in vivo (average about $55 \times 30$ ) and 40-56 $\times 19-32 \mu \mathrm{m}$ in silver nitrate preparations (average $47 \times 23 \mu \mathrm{m}$ ); length:width ratio 1.5-2.4:1 in vivo (average 1.8:1) and 1.7-2.4:1 (average 2.0:1) in silver nitrate preparations (Table 2). Body flexible but acontractile; slightly laterally compressed by about 1:1.3. Shape slender obovate; right body margin convex, left margin more or less straight and anteriorly projecting into an inconspicuous blunt rostrum occupied by oral apparatus (Fig. 1A, Hi-vii; 2A-C, E, F). Macronucleus in cell center, globular with a diameter of approximately $15 \mu \mathrm{m}$ in vivo; nucleoli evenly spaced over macronucleus, granular and about $3 \mu \mathrm{m}$ across (Fig. 1A; 2C, H; 3A-D). Micronucleus within macronuclear envelope, hemispherical and about $3 \times 2 \mu \mathrm{m}$ in size (Fig. $2 \mathrm{H}$ ). Contractile vacuole subterminal on ventrolateral side of body, empties via single excretory pore associated with somatic kinety 3 (Fig. 1A, B, Hi-vi; 2B-D, F; 4A, D). 
Cytopyge an argentophilic line anterior and left of excretory pore between somatic kineties 1 and 2 in silver nitrate preparations (Fig. 4D). Cortex thin, flexible, prominently furrowed, but sometimes smooth in globular overfed specimens; no cortical granules and, consequently, no extruded material recognizable in methyl green-pyronin stains (Fig. 4E-G). Mucocysts loosely spaced, globular with a diameter of about $1.2 \mu \mathrm{m}$, impregnate with silver carbonate but not protargol (Fig. 2F; 3A). Cytoplasm colorless or slightly pink-orange with scattered shiny 0.5-1 $\mu \mathrm{m}$-sized globules; usually numerous food vacuoles containing cyanobacteria (Fig. 2C, D). Swimming moderately slow rotating about long body axis, occasionally lingering over detritus.

Somatic cilia about $7 \mu \mathrm{m}$ long in vivo, paired and usually ordinarily spaced except for left posterior body area where they become more loosely arranged (Fig. 1B-D; 2B; 3A, D); anterior two pairs of dikinetids of somatic kinety 4 to kinety $n$ closely spaced and align to form two paratenes demarcating small anterior suture (Fig. 3A, black arrowheads). Somatic basal bodies associated with longitudinal fibres (LKm fibers) to left of somatic kineties in protargol preparations (Fig. 3B, C). Somatic kineties loosely spaced with interkinetal distance increasing in left posterior body area; extend in cortical furrows and converge on oral area anteriorly and contractile vacuole pore posteriorly; leftward spiraling and curving anteriorly over paroral membrane; more numerous on right than on left side of cell (Fig. 1A-D; 2A, B; 3A-D; 4A, C, D, H). Postoral kineties densely arranged, those on right side often shortened and consisting of only one or two dikinetids but not forming true postoral pseudomembranes, i.e., postoral kineties regularly alternating with pairs of dikinetids (Fig. 1B, D, black arrowheads; 3A, white arrowheads; 4A, black asterisk).

Silverline system irregular and comparatively complex, as typical for Etoschophrya. Generally platyophryid on right side of body (Fig. 1E; 4A, black arrowhead), but sometimes with small areas of disordered meridians or even transversely anastamosing silverlines (Fig. 4H, white arrowhead). Kreyellid pattern recognizable usually on left posterior body end, while three or more meshes formed in interkinetal spaces in anterior to mid-portion of cell (Fig. $4 \mathrm{C})$.

Oral apparatus on surface in left anterior fifth of cell (Fig. 1A, Hi-vii; 3B, 4A, D, H), appears slightly protuberant in vivo due to densely packed short cilia of paroral membrane and adoral organelles (Fig. 2A-G). Cytostome in center of oral apparatus, narrowly ovate and well recognizable in vivo and after silver nitrate impregnation (Fig. 2C, E, F; 4A, D). Cytopharyngeal basket hourglass-shaped and visible only in protargol-impregnated specimens (Fig. 4B, white arrowhead), not discernible in vivo or in silver carbonate preparations. Anterior three dikinetids of postoral and some left somatic kineties bear stout nematodesmata projecting from the anterior kinetosome towards the oral apparatus in silver carbonate preparations (Fig. 3D-G). Paroral membrane obliquely oriented to long body axis; almost closed, i.e., circular to elliptical in outline but open in its left anterior quadrant; composed of an average of 28 closely spaced dikinetids (Fig. 1A, B, D, E, G; 3A, B, D-G; 4A, D, H). Adoral zone composed of an average of five organelles, beginning at proximal end of paroral membrane and extending anteriorly in short preoral suture not reaching dorsal surface (Fig. 1A; Table 2). Adoral organelles very inconspicuous in vivo due to short ( $4 \mu \mathrm{m})$ cilia (Fig. 2A-C, E-G), but become prominent after silver carbonate and silver nitrate impregnation because each composed of two files of narrowly arranged basal bodies (Fig. 3A, B, D-G; 4A, D, H); each adoral organelle bears a short left fibrillar projection recognizable in silver carbonate preparations (Fig 3E, white arrowhead); first or second distalmost organelles often aligned parallel to long axis of cell (Fig. 1G; 3G, white arrowhead).

Resting cyst. Etoschophrya inornata sp. n. forms spherical resting cysts with two distinct layers enclosed by a hyaline mucous coat with adherent debris (Fig. 1I-K; 2I-K). Cyst formation begins as cells round up and secrete an inconspicuous mucous coat discernible only due to adherent debris (Fig. 2I). All food vacuoles and the contractile vacuole disappear within $24 \mathrm{~h}$. In the following days, the cell contents assume a homogeneous granular appearance. The slightly excentric macronucleus becomes quite inconspicuous, two distinct cyst wall layers are formed and the outer mucous coat thickens. Extruded material adheres to the outer layer (Fig. 1J; 2J, white asterisks). Somatic kineties and oral structures are very likely resorbed although this was not confirmed by silver impregnation. After two to three weeks the outer layer and mucous coat disappear and lines of cytoplasmic globules arranged in the same orientation as somatic kineties appear (Fig. 1K, 2K, white arrowheads). We did not observe excysting cells.

Occurrence and ecology. This report is based on a population of Etoschophrya inornata sp. n. from ephemeral puddles covering cushions of moss (Bryum argenteum and Encalypta vulgaris) on nonsaline dark sandy loam soil mixed with humic debris at the fenced margin of a grass sports field ( $\mathrm{pH} 7.0$ in water). Soil conductivity $\left(\mathrm{EC}_{1: 5}\right)$ was $103.8 \mu \mathrm{S} / \mathrm{cm}$ (estimated $\mathrm{EC}_{\mathrm{se}} 1.04 \mathrm{dS} / \mathrm{m}$ ) with total dissolved solids $71.8 \mathrm{mg} / \mathrm{L}$ and salinity of $51.7 \mathrm{ppm}$. Although 
samples contained abundant filamentous cyanobacteria (mainly from the families Nostocaceae and Oscillatoriaceae), macroscopic cyanobacterial crusts were not found at the type locality. We reviewed populations of previously unidentified woodruffiid ciliates from two permanent freshwater ponds $(0.47$ and 0.23 hectares $)$ within $3.5 \mathrm{~km}$ of the type location of E. inornata sp. n. Although we did not have detailed morphometric data from these populations, both appeared indistinguishable from $E$. inornata sp. n. based on in vivo differential interference microscopy and small numbers of silver carbonate impregnations. Like the congener E. oscillatoriophaga, all three populations of E. inornata sp. n. appeared to feed exclusively on filamentous cyanobacteria.

Molecular phylogenetic analysis. We performed several phylogenetic analyses based on three different alignments as described in the "Material and methods" section. The overall topology of all trees was identical but with slightly varying levels of nodal support. All analyses consistently placed E. inornata sp. n. and Kuklikophrya ougandae in a clade basal to the remaining platyophryids, including also two other woodruffiid taxa (Rostrophrya sp. and Woodruffides metabolicus), with strong to full support from all four statistical methods (Fig. 5). However, this polyphyly of the family Woodruffiidae is consistently rejected by the AU, WSH, and WKH tests because the constrained topology, in which the family Woodruffiidae is monophyletic (i.e., Etoschophrya, Kuklikophrya, Woodruffides and Rostrophrya clustering together), differs from the best unconstrained tree (Fig. 5) by a log likelihood (-ln L) of only 2.58 (Table 3).

Morphological phylogenies. The equally weighted parsimony analysis of the morphological matrix in PAUP* resulted in a basal polytomy of the order Platyophryida. Therefore, considering the molecular trees, we ascribed weight 5 to the following characters (for details, see Material and methods): shape of the paroral membrane (character 3), orientation of the adoral organelles (character 6), and localization of the micronucleus (character 12). This improved resolution among platyophryids significantly, yielding 31 most parsimonious trees of length 45 . The $50 \%$ majority-rule consensus topology had the following parameters: consistency index $(\mathrm{CI})=0.8222$, homoplasy index $(\mathrm{HI})=0.1778$, retention index $(\mathrm{RI})=0.8462$; three nodes collapsed. In this consensus tree, the order Platyophryida and the family Woodruffiidae were depicted as monophyletic, while the family Platyophryidae was shown as paraphyletic due to nesting of the families Sagittariidae and Sorogenidae (Fig. 6).

\section{Discussion}

\section{Comparison with related species}

Etoschophrya inornata sp. n. differs from its congener, E. oscillatoriophaga, by the following set of characters: (1) the absence of any interkinetal granules studding the cortex and, consequently, the absence of any extruded coat of red fibrous material with methyl green-pyronin staining; (2) usually $\geq$ five adoral membranelles vs. usually four; (3) greater length and length:width ratio; (4) prominent cortical furrows vs. inconspicuous; and (5) nonsaline nonalkaline Nearctic terrestrial and lentic habitats vs. highly saline (15-20\%o) alkaline (pH 8.7-9.0) Afrotropic terrestrial habitat. Although the shape of E. inornata sp. n. is similar to Kuklikophrya ougandae and both occur in similar habitats (we found the both species in the type location), the latter species (from the type location described above) is much larger (length about $100 \mu \mathrm{m}$ in vivo), has 10-18 adoral organelles, a more or less C-shaped paroral membrane, a funnel-shaped cytopharyngeal basket that is visible in vivo and several postoral kineties that curve sharply around the posterior end of the paroral membrane.

\section{Comparison of morphological and molecular trees}

The morphological consensus MP tree is basically congruent with those based on the 18S rRNA gene sequences, especially in that the order Platyophryida is monophyletic, the family Platyophryidae is paraphyletic, and the genera Ottowphrya and Sorogena are depicted as closely related. The family Woodruffiidae is monophyletic in the morphological trees, while polyphyletic in the unconstrained molecular phylogenies. On the other hand, the monophyletic origin of the Woodruffiidae is not rejected by the AU, WSH, and WKH tests (Table 3), corroborating the morphological classification of Foissner (1993) and Foissner et al. (2002, 2011). The phylogenetic position of the monotypic family Sagittariidae remains obscure, because it is nested within the paraphyletic family Platyophryidae in the morphological tree, while within the family Woodruffiidae in the molecular ones. Moreover, the topology tests do not reject the scenario in which Sagittaria represents a separate branch within the order Platyophryida, justifying the family rank suggested by Grandori \& Grandori (1935). Thus, the position of Sagittaria 
in the morphological tree is very likely artificial and caused by a combination of several homoplasic features (Fig. 6).

\section{Morphological homoplasies of platyophryids}

Our molecular and morphological phylogenies as well as the topology tests show that the evolutionary history of platyophryids is full of homoplasies, i.e., morphological traits that were formed convergently in fairly distantly related taxa. We recognized four features that evolved independently among platyophryids: body polarization, polymerization of adoral organelles, pseudomembranes, and silverline pattern. Moreover, using a molecular phylogenetic approach and statistical tests of various evolutionary scenarios, we revealed that even a combination of two or more homoplasies can co-occur in genetically fairly distant genera, Sorogena and Sagittaria being a good example. This makes the reconstruction of morphological evolution of platyophryids extremely difficult.

Body polarization. The oral apparatus extends in the anterior quarter on the ventral side of the cell in all platyophryids, except for Sorogena and Sagittaria which display a polar oral apparatus instead (Fig. 7). Although there are remarkable parallels between these two genera (colpodid silverline pattern, somatic and oral ciliature), the 18S rRNA gene phylogenies and all topology tests consistently reject their close relationship, demonstrating that body polarization probably evolved convergently in the two genera (Table 3).

Polymerization of adoral organelles. On the left vestibular slope there are 3-10 (usually 4) adoral organelles in the majority of platyophryid genera. However, there are typically many (10-18 in Kuklikophrya, 20-66 in Rostrophrya, and up to 90 in Woodriffides) adoral organelles in most members of the family Woodruffiidae. Thus, we statistically tested whether genera with few and many adoral organelles form a monophylum each. This hypothesis was firmly rejected by all topology tests applied at the conservative significance level of 0.01 (Table 3). In turn, both morphological and molecular phylogenies indicate that the lower number of adoral organelles is a plesiomorphic feature, and thus an inappropriate tool to unravel internal phylogenetic relationships among platyophryids (Fig. 5-7). Further, molecular phylogenies demonstrate that polymerization of adoral organelles occurred independently at least twice in the woodruffiid lineage, i.e., in Kuklikophrya on one side and in Woodruffides and Rostrophrya on the other one (Fig. 5). This also indicates that polymerization of the adoral organelles is not a very complex process, which could thus convergently take place in several other platyophryids (e.g., Platyophrya spumacola or P. similis).

Pseudomembranes. By definition, these are short postoral kineties composed of only two dikinetids each, which are regularly interposed between each two unshortened somatic kineties of the left side (Foissner 1993). Pseudomembranes together with the two anteriormost dikinetids of the left side kineties form a membranoid structure along the left margin of the oral aperture. To date pseudomembranes are properties of only two genera, Platyophrya and Rostrophryides. Foissner (1993) originally indicated convergent evolution in this trait by classifying them in different families. This is sustained by our cladistic analyses, as both genera do not cluster together in the MP morphological tree (Fig. 6). At the time of this writing, we still lack an SSU rRNA gene sequence for Rostrophryides, thus we cannot test whether the woodrufiid genera with pseudomembranes form a monophylum.

Silverline pattern. The strength of the silverline pattern as a character in the higher classification of colpodean ciliates has already been questioned (e.g., Lynn et al. 1999; Dunthorn et al. 2008, 2009; Bourland et al. 2011). Our phylogenetic analyses and topology tests demonstrate parallel evolution at an even lower (i.e., infrafamilial) level. Altogether three basic silverline patterns have been found within the order Platyophryida: colpodid, kreyellid and platyophryid. Further, there are several genera that exhibit a highly derived composite silverline pattern: Etoschophrya and Reticulowoodruffia have a mixed platyophryid and kreyellid pattern, while Semiplatyophrya displays platyophryid and colpodid patterns. Etoschophrya even shows patchy areas with three or four interkinetal meshes (Fig. 4C), reminiscent of the silverline pattern of Reticulowoodruffia (Foissner 1993). Morphological phylogenies suggest that each genus evolved its silverline pattern independently (Fig. 6). Based on the molecular and morphological trees as well as the topology tests, it is evident that the colpodid silverline pattern was formed convergently four times within the order Platyophryida: in Woodruffia, Platyophryides, Sagittaria, and Sorogena (Fig. 5, 6; Table 3). 


\section{Ground pattern of platyophryids}

Ground pattern is thea combination of apomorphies and younger plesiomorphies present in the stem species (last common ancestor) from which the monophylum evolved (Ax 1995). Looking at the morphology of the extant platyophryids and cyrtolophosidids as well as at the morphological and 18S rRNA gene phylogenies, we hypothesize that the last common ancestor of the order Platyophryida had the following features: (1) oblong body with oral apparatus extending in the anterior quarter on the ventral side of the cell; (2) a single micronucleus in the perinuclear space of the macronucleus; (3) J-shaped, uninterrupted paroral membrane composed of dikinetids throughout; (4) adoral zone of membranelles shorter than the paroral membrane and comprising four organelles oriented obliquely to the paroral; (5) no pseudomembranes or postoral kineties; (and (6) platyophryid silverline pattern on the whole cell surface (Fig. 7).

Body shape and localization of oral apparatus. The body is oblong and the oral apparatus is situated in the anterior quarter on the ventral side of the cell in the outgroup and most platyophryids (Foissner 1993). Therefore, this general body organization is included in the ground pattern of platyophryids. There are only two platyophryid genera, Sorogena and Sagittaria, which deviate from this pattern in that their oral apparatus is situated on the anterior body end (Bradbury \& Olive 1980; Foissner et al. 1981; Foissner 1987a, 1993; Pomp \& Wilbert 1988). This polar position of the oral apparatus is considered as a special feature (see also section on homoplasies), which was not present in the stem species of the platyophryids.

Nuclear apparatus. The single micronucleus is resided in the perinuclear space of the macronucleus in the outgroup and most platyophryids (Foissner 1993). The sole exceptions are Sorogena, Platyophryides and Ottowphrya, in which the micronucleus is delimited by its own membrane and separated from the macronucleus (Bradbury \& Olive 1980; Puytorac et al. 1992; Foissner 1993; Foissner et al. 2002). All three genera form a well supported monophylum, the family Sorogenidae, which is nested rather deep within the order Platyophryida in both morphological and molecular phylogenies. Thus, the localization of the micronucleus in the perinuclear space of the macronucleus is included in the ground pattern of platyophryids, while the macronucleus and micronucleus surrounded by their own membranes are considered as an apomorphy of the family Sorogenidae.

Paroral membrane. The paroral membrane is usually curved (J- or C-shaped), dikinetidal, and bipartited in the outgroup (Dunthorn et al. 2009; Foissner 1993; Quintela-Alonso et al. 2011). A curved and dikinetidal paroral membrane is found also in other colpodeans (e.g., grossglockneriids, some bryophryids and bryometopids), including all platyophryids. On the other hand, the bipartition of the paroral membrane in cyrtolophosidids is unique within the class Colpodea, and it is thus considered as their most important apomorphic character (Foissner 1993), as also corroborated by molecular phylogenies (e.g., Dunthorn et al. 2009; Quintela-Alonso et al. 2011). Therefore, we assume that the paroral membrane of the last common ancestor of platyophryids was curved, uninterrupted and composed of dikinetids throughout.

Adoral organelles. The adoral zone of organelles is shorter than the paroral membrane and usually comprises four organelles oriented obliquely to the paroral in the outgroup. Most platyophryid genera also possess four oblique adoral organelles. This pattern is thus considered as ancestral for the order Platyophryida. Polymerization of the adoral organelles occurred only in a few platyophryid genera (see section on homoplasies above), and the adoral organelles changed orientation from oblique to parallel with respect to the paroral membrane only in two closely related genera, Platyophryides and Ottowphrya. Both, the higher number of the adoral organelles and the parallel orientation of the adoral organelles are considered as derived features of some platyophryids and were thus very likely not present in the stem species of platyophryids.

Pseudomembranes and postoral kineties. These ciliary structures do not occur in the outgroup and are properties of only a few platyophryid genera. Namely, Platyophrya and Rostrophryides have pseudomembranes, while Kuklikophrya displays postoral kineties. Therefore, we do not include these special structures into the ground pattern of platyophryids, but consider them as apomorphies of the aforementioned genera.

Silverline pattern. The platyophryid siliverline pattern is most widespread among platyophryids, while the outgroup and a few platyophryid genera (e.g., Woodruffia or Sorogena) possess a colpodid silverline pattern. However, small body regions of the cyrtolophosidids display a platyophryid pattern and, in addition, the colpodid silverline pattern is transformed into a platyophryid configuration during cell division of Cyrtolophosis mucicola and 
Pseudocyrtolophosis alpestris (Foissner 1980, 1993). Therefore, Foissner (1993) assumed that the colpodid silverline pattern of cyrtolophosidids and some platyophryid genera is an apomorphic feature and, consequently, the platyophryid silverline pattern was very likely a property of the stem species of the order Platyophryida.

\section{Reconstruction of woodruffiid evolutionary history}

Based on the ground pattern of platyophryids, we suppose that the last common ancestor of the family Woodruffiidae maintained the ventral oral apparatus and the localization of the micronucleus in the perinuclear space, but its body became rostrate taking along the adoral zone of membranelles which extends beyond the paroral membrane, forming together a $\delta$-shaped pattern. As concerns morphology of the paroral membrane, we recognized two lineages within this family. In the first lineage, comprising Kuklikophrya and Etoschophrya, the paroral membrane is almost closed to form a "circumoral kinety". On the contrary, the paroral membrane forms a more open C-shaped pattern in the second lineage, which includes Rostrophrya, Rostrophryides, Woodruffia and Woodruffides (Fig. 7).

As concerns the morphological evolution of the first lineage, we assume that Etoschophrya maintained the ancestral low number of adoral organelles, but evolved a complex silverline pattern which is platyophryid on the right side of the cell, while mostly kreyellid on the left one. On the other hand, Kuklikophrya very likely retained the ancestral platyophryid silverline pattern, but developed curved postoral kineties and doubled the number of adoral organelles.

We suppose that the last common ancestor of the second lineage increased the number of adoral organelles, a trait that evolved convergently in Kuklikophrya according to the topology tests (see above and Table 3). The adoral zone of membranelles is only slightly longer (1-3 organelles) than the paroral membrane in Woodruffia, Woodruffides and Rostrophryides, while distinctly longer, extending to the top of the rostrum, in Rostrophrya. We could not recognize any further morphological novelty in Woodruffides, while we hypothesize that Woodruffia transformed the platyophryid silverline pattern into a colpodid one, and Rostrophryides developed pseudomembranes. These two morphological apomorphies are, however, homoplastic as they evolved independently also in other genetically fairly distant genera (see section on homoplasies).

\section{Acknowledgements}

Ther authors are grateful to Prof. Dr. WILHELM FoISSNER and to Prof. Dr. DENIS LYNN for their helpful taxonomic insights and also to two anonymous reviewers for their positive criticisms that helped improve the manuscript.. This work was partially supported by the Slovak Scientific Grant Agency (VEGA projects 1/0600/11 and 1/0124/09) and by start up funds from the Boise State University Biology Department. 


\section{References}

Armstrong, R. D. (2009). Salinity and sodicity. In R. D. Armstrong (Ed.) Identifying, understanding and managing hostile subsoils for cropping (pp. 39-46). Adelaide: The Profitable Soils Group. Available via http://www.dpi.vic.gov.au/dpi/vro/vrosite.nsf/pages/soil_mgmt_subsoil.

Ax, P. (1995). Das System der Metazoa I. Ein Lehrbuch der phylogenetischen Systematik. Stuttgart: Gustav Fischer Verlag.

Bardele, C. F., Foissner, W. \& Blanton, R. L. (1991). Morphology, morphogenesis and systematic position of the sorocarp forming ciliate Sorogena stoianovitchae Bradbury \& Olive, 1980. Journal of Protozoology, 38, 7-17.

Bourland, W. A., Vd’ačný, P., Davis, M. C. \& Hampikian, G. (2011). Morphology, morphometrics, and molecular characterization of Bryophrya gemmea n. sp. (Ciliophora, Colpodea): Implications for the phylogeny and evolutionary scenario for the formation of oral ciliature in the order Colpodida. Journal of Eukaryotic Microbiology, 58, 22-36.

Bradbury, P. C. \& Olive, L. S. (1980). Fine structure of the feeding stage of a sorogenic ciliate, Sorogena stoianovitchae gen. n., sp. n. Journal of Protozoology, 27, 267-277.

Castresana, J. (2000). Selection of conserved blocks from multiple alignments for their use in phylogenetic analysis. Molecular Biology and Evolution, 17, 540-52.

Dopheide, A., Lear, G., Stott, R. \& Lewis, G. (2008). Molecular characterization of ciliate diversity in stream biofilms. Applied and Environmental Microbiology, 74, 1740-1747.

Dragesco, J. \& Dragesco-Kernéis, A. (1986). Ciliès libres de l'Afrique intertropicale. Collection Faune Tropicale, Paris, 26, 1-559.

Dunthorn, M., Foissner, W. \& Katz, L. A. (2008). Molecular phylogenetic analysis of class Colpodea (phylum Ciliophora) using broad taxon sampling. Molecular Phylogenetics and Evolution, 46, 316-327.

Dunthorn, M., Schwarz, M. V. J., Eppinger, M., Schweikert, M., Boenigk, J., Katz, L. A. \& Stoeck, T. (2009). Phylogenetic placement of the Cyrtolophosididae Stokes, 1888 (Ciliophora, Colpodea) and neotypification of Aristerostoma marinum Kahl, 1931. International Journal of Systematic and Evolutionary Microbiology, 59, 167-180.

Foissner, W. (1980). Colpodide Ciliaten (Protozoa: Ciliophora) aus alpinen Böden. Zoologische Jahrbücher Systematik, 107, 391-432.

Foissner, W. (1987a). Neue und wenig bekannte hypotriche und colpodide Ciliaten (Protozoa: Ciliophora) aus Böden und Moosen. Zoologische Beiträge (Neue Folge), 31, 187-282.

Foissner, W. (1987b). Miscellanea nomenclatorica ciliatea (Protozoa: Ciliophora). Archiv für Protistenkunde, 133, 219-235.

Foissner, W. (1991). Basic light and scanning electron microscopic methods for taxonomic studies of ciliated protozoa. European Journal of Protistology, 27, 313-330.

Foissner, W. (1993). Colpodea (Ciliophora). Protozoenfauna, 4/1, 1-798. 
Foissner, W. (2010). Life cycle, morphology, ontogenesis, and phylogeny of Bromeliothrix metopoides nov. gen., nov. spec., a peculiar ciliate (Protista, Colpodea) from tank bromeliads (Bromeliaceae). Acta Protozoologica, 49, 159-193.

Foissner, W. \& Xu, K. (2007). Monograph of the Spathidiida (Ciliophora, Haptoria). Vol. I: Protospathidiidae, Arcuospathidiidae, Apertospathulidae. Monographiae Biologicae, 81, 1-485.

Foissner, W., Czapik, A. \& Wiackowski, K. (1981). Die Infraciliatur und das Silberliniensystem von Sagittaria hyalina nov. spec., Chlamydonella polonica nov. spec. und Spirozona caudata Kahl, 1926 (Protozoa, Ciliophora). Archiv für Protistenkunde, 124, 361-377.

Foissner, W., Agatha, S. \& Berger, H. (2002). Soil ciliates (Protozoa, Ciliophora) from Namibia (Southwest Africa), with emphasis on two contrasting environments, the Etosha Region and the Namib Desert. Denisia, 5, 1-1459.

Foissner, W., Stoeck, T., Agatha, S. \& Dunthorn, M. (2011). Intraclass evolution and classification of the Colpodea (Ciliophora). Journal of Eukaryotic Microbiology, 58, 397-415.

Grain, J., Iftode, F. \& Fryd-Versavel, G. (1979). Étude des infraciliatures somatique et buccale de Bryophrya bavariensis et considérations systématiques. Protistologica, 15, 581-595.

Grandori, R. \& Grandori, L. (1935) Rettifiche di nomenclatura zoologica. Bollettino di zoologia agraria e di bachicoltura Rendiconti - Istituto superiore di agricoltura Milano, 6 (years 1934-35), 3.

Griekspoor, A. \& Groothuis, T. (2006). 4Peaks. Available via http://mekentosj.com.

Hoeck, A. H. A. M. van, Sprakel, V. S. I., Hackstein, J. H. P. \& Vogels, G. D. (1998). Evolution of anaerobic ciliates from the gastrointestinal tract: Phylogenetic analysis of the ribosomal repeat from Nyctotherus ovalis and its relatives. Molecular Biology and Evolution, 15,1195-206.

Huang, X. \& Madan, A. (1999). CAP3: A DNA sequence assembly program. Genome Research, 9, 868-877.

Katoh, K. \& Toh, H. (2008). Recent developments in the MAFFT multiple sequence alignment program. Briefings in Bioinformatics, 9, 286-98.

Lynn, D. H. (2008). The ciliated protozoa: Characterization, classification and guide to the literature. 3rd ed. Dordrecht: Springer.

Lynn, D. H., Wright, A.-D. G., Schlegel, M. K. \& Foissner, W. (1999). Phylogenetic relationships of orders within the class Colpodea (Phylum Ciliophora) inferred from small subunit rRNA gene sequences. Journal of Molecular Evolution, 48, 605-14.

Medlin, L. K., Elwood, H. J., Stickel, S. \& Sogin, M. L. (1988). The characterization of enzymatically amplified eukaryotic 16S-like rRNA-coding regions. Gene, 71, 491-499.

Miller, M. A., Holder, M. T., Vos, R., Midford, P. E., Liebowitz, T., Chan, L., Hoover, P. \& Warnow, T. (2009). The CIPRES Portals. Available via http://www.phylo.org/sub_sections/portal.

Njiné, T. (1979). Etude ultrastructurale du cilié Kuklikophrya dragescoi gen. n., sp. n. Journal of Protozoology, 26, 589-598.

Pomp, R. \& Wilbert, N. (1988). Taxonomic and ecological studies of ciliates from Australian saline soils: colpodids and hymenostomate ciliates. Australian Journal of Marine and Freshwater Research, 39, 479-495. 
Posada, D. \& Crandall, K. A. (1998). MODELTEST: testing the model of DNA substitution. Bioinformatics, 14, $817-818$.

Puytorac, P. de, Perez-Paniagua, F. \& Perez-Silva, J. (1979). A propos d'observations sur la stomatogenèse et l'ultrastructure du cilié Woodruffia metabolica (Johnson et Larson, 1938). Protistologica, 15, 231-243.

Puytorac, P. de, Kattar, M. R., Grolière, C. A. \& Silva Neto, I. da (1992). Polymorphism and ultrastructure of a colpodean ciliate of the genus Platyophryides Foissner, 1987. Journal of Protozoology, 39, 154-159.

Quintela-Alonso, P., Nitsche, F. \& Arndt, H. (2011). Molecular characterization and revised systematics of Microdiaphanosoma arcuatum (Ciliophora, Colpodea). Journal of Eukaryotic microbiology, 58, 114-119.

Ronquist, F. \& Huelsenbeck, J. P. (2003). MrBayes 3: Bayesian phylogenetic inference under mixed models. Bioinformatics, 19,1572-1574.

Shimodaira, H. \& Hasegawa, M. (2001). Consel: for assessing the confidence of phylogenetic tree selection. Bioinformatics, 17, 1246-1247.

Stamatakis, A., Hoover, P. \& Rougemont, J. (2008). A rapid bootstrap algorithm for the RAxML web-servers. Systematic Biology, 75, 758-771.

Strüder-Kypke, M. C. \& Lynn, D. H. (2003). Sequence analyses of the small subunit rRNA gene confirm the paraphyly of oligotrich ciliates sensu lato and support the monophyly of the subclasses Oligotrichia and Choreotrichia (Ciliophora, Spirotrichea). Journal of Zoology (London), 260, 87-97.

Swofford, D. L. (2001). PAUP*. Phylogenetic Analysis Using Parsimony (*and Other Methods). Ver. 4. [Computer software and manual]. Sunderland, Massachusetts: Sinauer Associates.

Talavera, G. \& Castresana, J. (2007). Improvement of phylogenies after removing divergent and ambiguously aligned blocks from protein sequence alignments. Systematic Biology, 56, 564-577.

Wiens, J. J. (2000). Coding morphological variation for phylogenetic analysis. In J. J. Wiens (Ed.) Phylogenetic Analysis of Morphological Data (pp. 115-145). Washington: Smithsonian Institution Press.

Wilbert, N. \& Kahan, D. (1986). Semiplatyophrya foissneri nov. gen, nov. spec. und Perisincirra pori nov. spec., Ciliaten aus einem Salzboden des Sinai. Archiv für Protistenkunde, 131, 129-138.

Wylezich, C., Meisterfeld, R., Meisterfeld, S. \& Schlegel, M. (2002). Phylogenetic analyses of small subunit ribosomal RNA coding regions reveal a monophyletic lineage of euglyphid testate amoebae (Order Euglyphida). Journal of Eukaryotic Microbiology, 49, 108-118. 
Table 1. List of ciliate species with GenBank (GB) accession numbers of corresponding 18S rRNA gene sequences included in the phylogenetic analyses. New colpodean sequences are shown in bold.

\begin{tabular}{|c|c|c|c|c|c|}
\hline Species name & GB number & Species name & GB number & Species name & GB number \\
\hline $\begin{array}{l}\text { Bromeliothrix metopoides } \\
\text { (Rio de Janeiro) }\end{array}$ & NA123456 & Colpoda steinii & DQ388599 & Platyophrya bromelicola & EU039906 \\
\hline \multirow{2}{*}{ Bryometopus pseudochilodon } & & Etoschophrya innornata & & & \\
\hline & EU039887 & inornata $\mathbf{n} . \mathbf{s p}$. & NA123457 & Pseudocyrtolophosis alpestris & EU264564 \\
\hline Bryophrya gemmea & HQ337901 & Furgasonia blochmanni & X65150 & Pseudoplatyophrya nana & AF060452 \\
\hline Bursaria truncatella & U82204 & Ilsiella palustris & EU039901 & Rostrophrya sp. & EU039907 \\
\hline Colpoda henneguyi & EU039894 & Mykophagophrys terricola & EU039902 & Woodruffides metabolicus & NA123459 \\
\hline Colpoda lucida & EU039895 & Notoxoma parabryophryides & EU039903 & & \\
\hline
\end{tabular}

${ }^{a}$ Junior synonym for O. aurea (Foissner 1987). 
Table 2. Morphometric data from silver impregnated Etoschophrya inornata sp. n.

\begin{tabular}{|c|c|c|c|c|c|c|c|c|c|}
\hline Characteristics $^{\mathrm{a}}$ & Method $^{b}$ & Mean & $\mathrm{M}$ & SD & $\mathrm{CV}$ & Min & Max & $\mathrm{n}$ & $\begin{array}{c}\% \\
\text { increase }^{\mathrm{d}}\end{array}$ \\
\hline Body, length & $\mathrm{CL}$ & 47.3 & 46.7 & 4.63 & 9.8 & 40.2 & 56.0 & 40 & 51.0 \\
\hline Body, width & CL & 23.4 & 23.0 & 2.76 & 11.8 & 18.9 & 31.7 & 40 & -6.6 \\
\hline $\begin{array}{l}\text { Body, length:width } \\
\text { ratio }\end{array}$ & CL & 2.0 & 2.1 & 0.18 & 8.9 & 1.7 & 2.4 & 40 & $60.4^{\mathrm{f}}$ \\
\hline $\begin{array}{l}\text { Anterior end to } \\
\text { proximal }\end{array}$ & CL & 9.4 & 9.2 & 1.27 & 13.5 & 7.4 & 12.9 & 40 & $19.0^{*}$ \\
\hline $\begin{array}{l}\mathrm{POM}, \text { distance } \\
\text { Anterior end to } \\
\text { macronucleus, } \\
\text { distance }\end{array}$ & $\mathrm{CL}$ & 23.9 & 23.4 & 4.12 & 17.3 & 17.2 & 36.3 & 38 & 64.8 \\
\hline Macronucleus, length & $\mathrm{CL}$ & 8.4 & 8.3 & 0.85 & 10.0 & 6.9 & 11.4 & 34 & 23.5 \\
\hline Macronucleus, width & $\mathrm{CL}$ & 7.7 & 7.6 & 0.94 & 12.3 & 5.6 & 10.2 & 34 & 15.0 \\
\hline Macronuclei, number & $\mathrm{CL}$ & 1.0 & 1.0 & - & - & 1.0 & 1.0 & 40 & 0 \\
\hline Micronucleus, length & CL & 2.4 & 2.4 & 0.71 & 14.8 & 2.0 & 3.4 & 32 & - \\
\hline Micronucleus, width & $\mathrm{CL}$ & 2.0 & 2.0 & 0.31 & 15.4 & 1.5 & 2.9 & 32 & - \\
\hline Micronuclei, number & CL & 1.0 & 1.0 & - & - & 1.0 & 1.0 & 32 & 0 \\
\hline $\begin{array}{l}\text { Somatic kineties, } \\
\text { number }\end{array}$ & $\mathrm{CL}, \mathrm{SC}$ & 21.7 & 21.0 & 1.36 & 6.3 & 19 & 25 & 49 & 21.9 \\
\hline $\begin{array}{l}\text { Dikinetids in kinety } 3 \text {, } \\
\text { number }\end{array}$ & $\mathrm{CL}, \mathrm{SC}$ & 17.6 & 16.5 & 2.59 & 14.7 & 15 & 24 & 28 & 10.7 \\
\hline $\begin{array}{l}\text { Postoral kineties, } \\
\text { number }\end{array}$ & SC & 7.4 & 7.0 & 1.17 & 15.9 & 5.0 & 9.0 & 45 & - \\
\hline POM, length & $\mathrm{CL}$ & 5.8 & 5.7 & 0.53 & 9.2 & 4.7 & 6.9 & 39 & -12.2 \\
\hline POM, width & CL & 4.2 & 4.3 & 0.39 & 9.4 & 3.2 & 4.8 & 39 & -12.5 \\
\hline $\begin{array}{l}\text { POM dikinetids, } \\
\text { number }\end{array}$ & $\mathrm{SC}$ & 27.7 & 27.0 & 2.06 & 7.4 & 24.0 & 33.0 & 34 & 16.4 \\
\hline $\begin{array}{l}\text { Adoral organelles, } \\
\text { number }\end{array}$ & $\mathrm{SC}$ & 5.2 & 5.0 & 0.44 & 8.5 & 4.0 & 6.0 & 46 & 30.0 \\
\hline
\end{tabular}


${ }^{\mathrm{b}} \mathrm{CL}$ (Chatton-Lwoff silver nitrate, permanent preparations; SC, silver carbonate, temporary preparations.

${ }^{\mathrm{c}}$ Distance from anterior end to vertex of paroral membrane.

${ }^{\mathrm{d}} \%$ Increase in the median value for E. innornata n. sp. relative to E. oscillatoriophaga (Foissner et al. 2002).

${ }^{\mathrm{e}}$ Of $71 \mathrm{SC}$ impregnated individuals examined one had seven adoral organelles. Of 46 adequately impregnated individuals $45(98 \%)$ had $\geq 5$ adoral organelles.

${ }^{\mathrm{f}}$ Data (S.D.) for E. oscillatoriophaga unavailable for statistical analysis. 
Table 3. Log likelihoods and P-values of AU (approximately unbiased), WSH (weighted Shimodaira-Hasegawa), and WKH (weighted Kishino-Hasegawa) tests for tree comparisons considering different topological scenarios. Significant differences $(\mathrm{P}$-value $<0.05)$ between the best unconstrained and constrained topologies are in bold.

\begin{tabular}{|c|c|c|c|c|c|c|}
\hline Topology & $\begin{array}{l}\text { Log likelihood } \\
(-\ln \mathrm{L})\end{array}$ & $\begin{array}{l}\text { Difference to best } \\
\text { tree }(-\ln L)\end{array}$ & $\mathrm{AU}$ & WSH & WKH & Conclusion \\
\hline Best maximum likelihood tree (unconstrained) & 7855.8626 & - & - & - & - & - \\
\hline Monophyly of Platyophryida and Cyrtolophosidida & 7893.8132 & 37.95 & 0.001 & 0.005 & 0.001 & Rejected \\
\hline $\begin{array}{l}\text { Monophyly of Woodruffiidae sensu Foissner (1993) and Foissner et al. (2002), i.e., } \\
\text { Etoschophrya, Kuklikophrya, Rostrophrya, and Woodruffides form a } \\
\text { monophylum }\end{array}$ & 7858.4414 & 2.58 & 0.201 & 0.654 & 0.177 & Not rejected \\
\hline $\begin{array}{l}\text { Monophyly of Platyophryidae sensu Foissner (1993), i.e., Platyophrya spp. and } \\
\text { Ottowphrya excluding Sorogena }\end{array}$ & 7881.1496 & 25.29 & 0.005 & $\mathbf{0 . 0 3 1}$ & 0.011 & Rejected \\
\hline $\begin{array}{l}\text { Monophyly of polar platyophryids with colpodid silverline pattern, i.e., Sorogena } \\
\text { and Sagittaria form a monophylum }\end{array}$ & 7989.4460 & 133.58 & 2e-041 & 0.000 & 0.000 & Rejected \\
\hline Sorogena as a separate lineage within Platyophryida & 7892.7531 & 36.89 & 0.001 & 0.018 & 0.006 & Rejected \\
\hline Sagittaria as a separate lineage within Platyophryida & 7861.5271 & 5.66 & 0.084 & 0.411 & 0.114 & Not rejected \\
\hline $\begin{array}{l}\text { Monophyly of platyophryids with less than } 10 \text { adoral organelles, i.e., } \\
\text { Etoschophrya, Ottowphrya, Platyophrya, Sagittaria and Sorogena form a } \\
\text { monophylum }\end{array}$ & 7997.1862 & 141.32 & 5e-037 & 0.000 & 0.000 & Rejected \\
\hline $\begin{array}{l}\text { Monophyly of platyophryids with more than } 10 \text { adoral organelles, i.e., } \\
\text { Kuklikophrya, Rostrophrya, and Woodruffides form a monophylum }\end{array}$ & 7981.1277 & 125.26 & $4 e-040$ & 0.000 & 0.000 & Rejected \\
\hline
\end{tabular}


Table 4. Characters, character states, and coding used for the cladogram shown in Figure 2. For distribution of character states in the taxa, see Table 5.

\begin{tabular}{|c|c|c|c|}
\hline No. & Character & Plesiomorphic & Apomorphic \\
\hline 1 & Body shape & Ellipsoidal (coded 0) & $\begin{array}{l}\text { Rostrate (coded 1) } \\
\text { Obliquely truncate (coded 2) } \\
\text { Polar (coded 3) }\end{array}$ \\
\hline 2 & Oral opening, localization & Subapical (coded 0) & $\begin{array}{l}\text { Near anterior end (coded 1) } \\
\text { At anterior end (coded 2) }\end{array}$ \\
\hline 3 & Paroral membrane & J-shaped (coded 0$)$ & $\begin{array}{l}\text { Almost closed (coded 1) } \\
\text { C-shaped (coded 2) }\end{array}$ \\
\hline 4 & Paroral membrane gap & No $($ coded 0$)$ & Yes $(\operatorname{coded} 1)$ \\
\hline 5 & Adoral organelles, number & Usually 4 (coded 0$)$ & Usually > $10($ coded 1$)$ \\
\hline 6 & Adoral organelles, orientation & Oblique to paroral (coded 0$)$ & Parallel to paroral (coded 1) \\
\hline 7 & Adoral zone of organelles, length & Shorter than paroral (coded 0) & $\begin{array}{l}\text { As long as paroral (coded } 1) \\
\text { Slightly longer than paroral (coded } 2) \\
\text { Distinctly longer than paroral (coded } 3)\end{array}$ \\
\hline 8 & Postoral kineties & No (coded 0$)$ & Yes $(\operatorname{coded} 1)$ \\
\hline 9 & Pseudomembranes & No $(\operatorname{coded} 0)$ & Yes $(\operatorname{coded} 1)$ \\
\hline 10 & Oblique kinety & No (coded 0$)$ & Yes (coded 1$)$ \\
\hline 11 & Silverline pattern & Platyophryid (coded 0) & $\begin{array}{l}\text { Colpodid (coded 1) } \\
\text { Composite platyophryid and colpodid } \\
\quad \text { (coded 2) } \\
\text { Composite platyophryid and kreyellid } \\
\quad \text { (coded 3) }\end{array}$ \\
\hline 12 & Micronucleus in perinuclear space & Yes $(\operatorname{coded} 0)$ & No $($ coded 1$)$ \\
\hline 13 & Sorocarp production & No (coded 0$)$ & Yes $(\operatorname{coded} 1)$ \\
\hline
\end{tabular}


Table 5. Distribution of characters and their coding in the taxa for the computer program PAUP*. For characters and character states, see Table 4. Explanations: ? = not known.

\begin{tabular}{llllll}
\hline TaxaTaxon & \multicolumn{4}{l}{ Characters } \\
\cline { 2 - 6 } & 1,2 & 3,4 & $5-7$ & $8-10$ & $11-13$ \\
\hline Cyrtolophosis & 00 & 01 & 000 & 001 & 000 \\
Pseudocyrtolophosis & 00 & 01 & 000 & 000 & 000 \\
Kuklikophrya & 10 & 10 & 103 & 100 & 000 \\
Etoschophrya & 10 & 10 & 002 & 000 & 300 \\
Woodruffia & 10 & 20 & 102 & 000 & 100 \\
Woodruffiddes & 10 & 20 & 102 & 000 & 000 \\
Rostrophryides & 11 & 20 & 102 & 010 & 000 \\
Rostrophrya & 10 & 20 & 103 & 000 & 000 \\
Sagittaria & 32 & 20 & 001 & 000 & 100 \\
Semiplatyophrya & 20 & 20 & 001 & 000 & 200 \\
Reticulowoodruffia & 10 & 20 & 001 & 000 & 300 \\
Platyophrya & 21 & 20 & 001 & 010 & 000 \\
Platyophryides & 21 & 20 & 011 & 000 & $11 ?$ \\
Ottowphrya & 21 & 20 & 011 & 000 & $01 ?$ \\
Sorogena & 22 & 20 & 001 & 000 & 111 \\
\hline
\end{tabular}




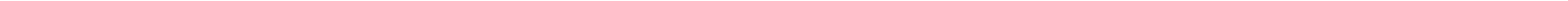


(1) 3

$\cos (5)$

$y_{3}(x)<y$

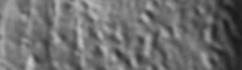

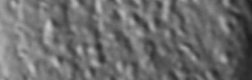

cosigy,

$50 \sin 2$

3.

inswise

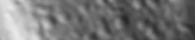

$\log ^{2} \sin ^{2}$

tes

\section{A}

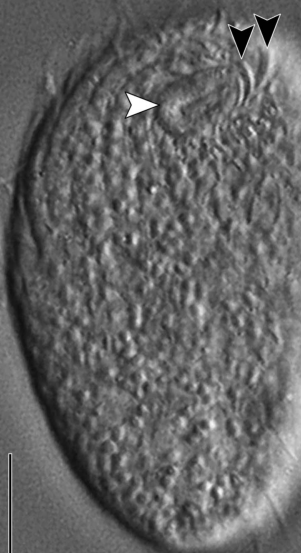

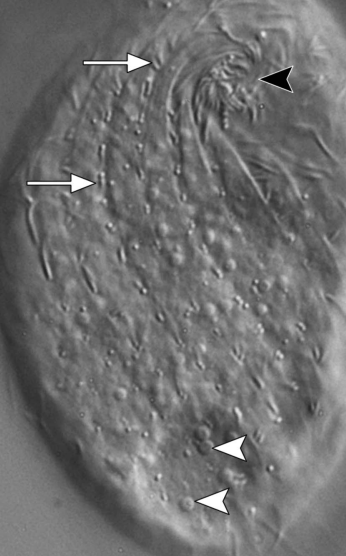

B
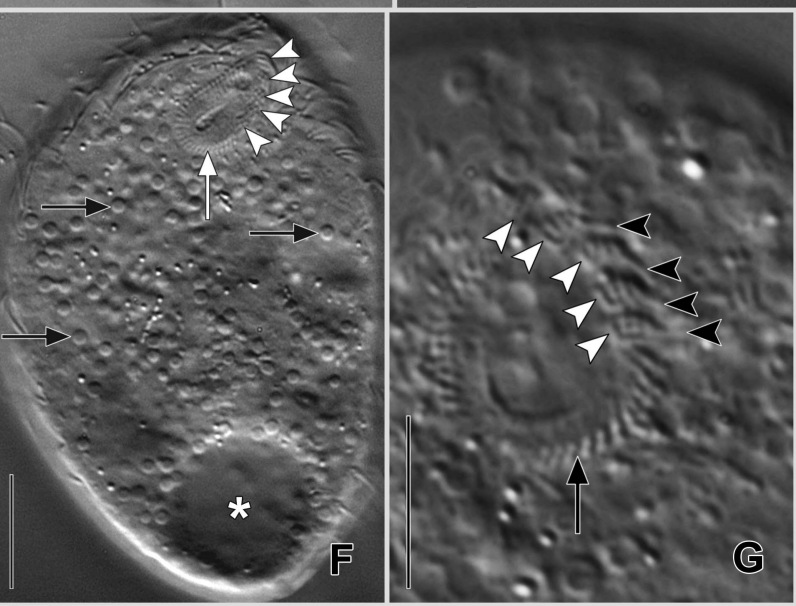

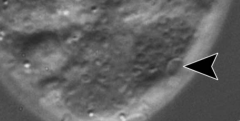

G

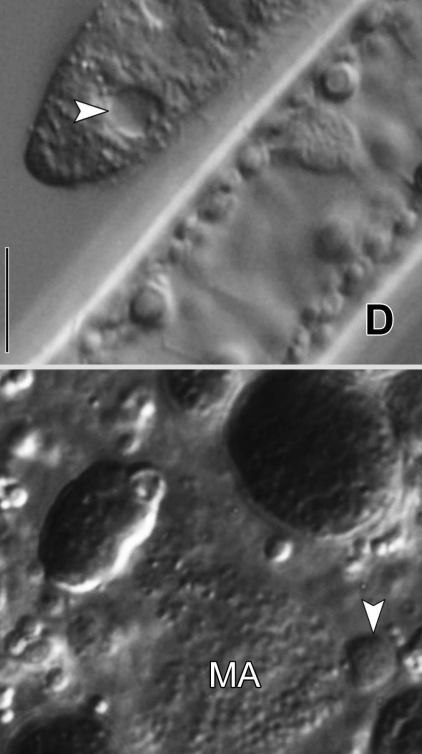
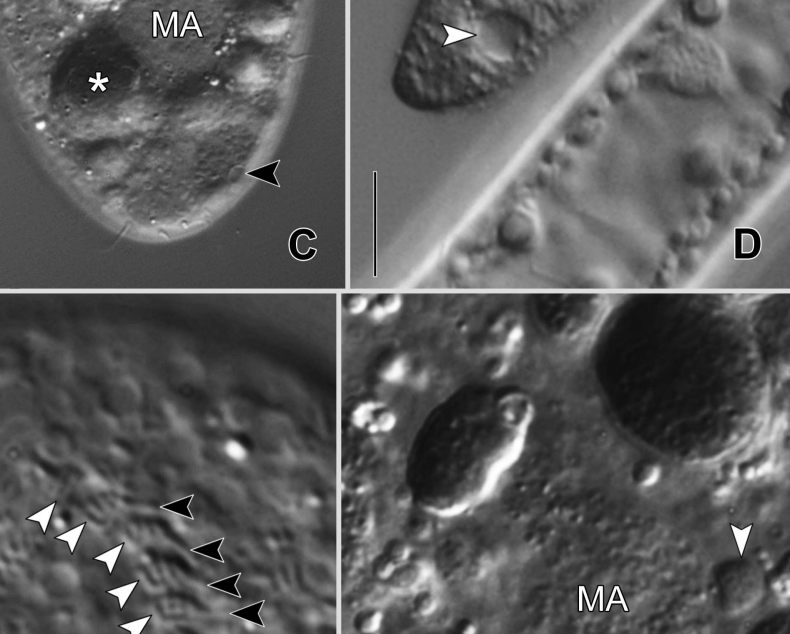

3
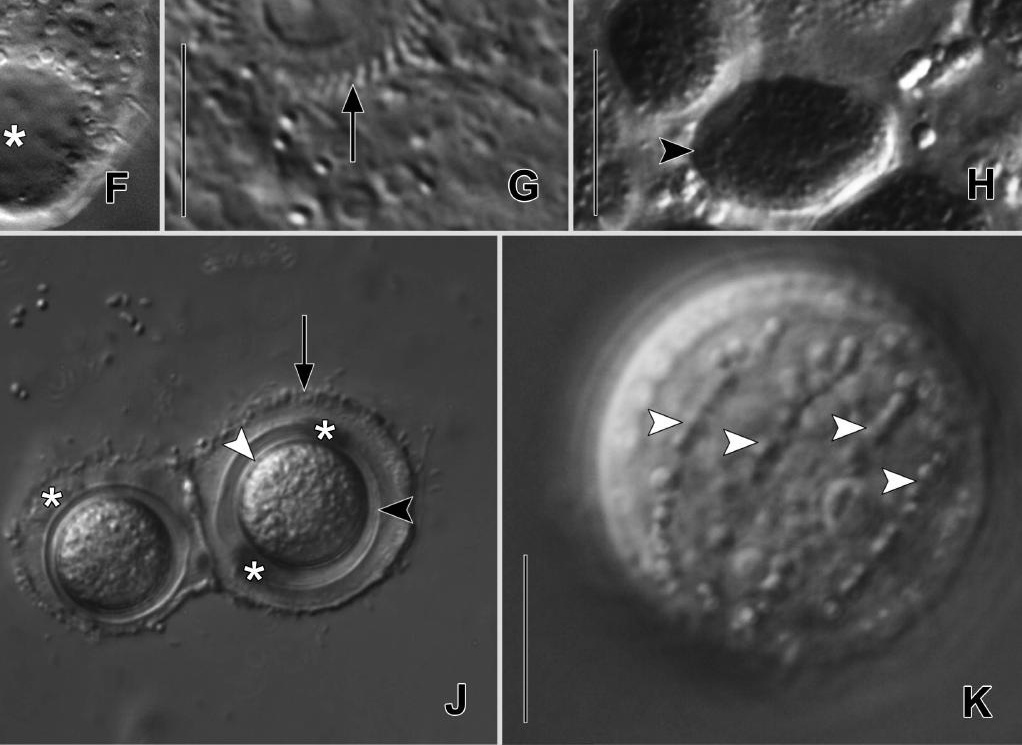



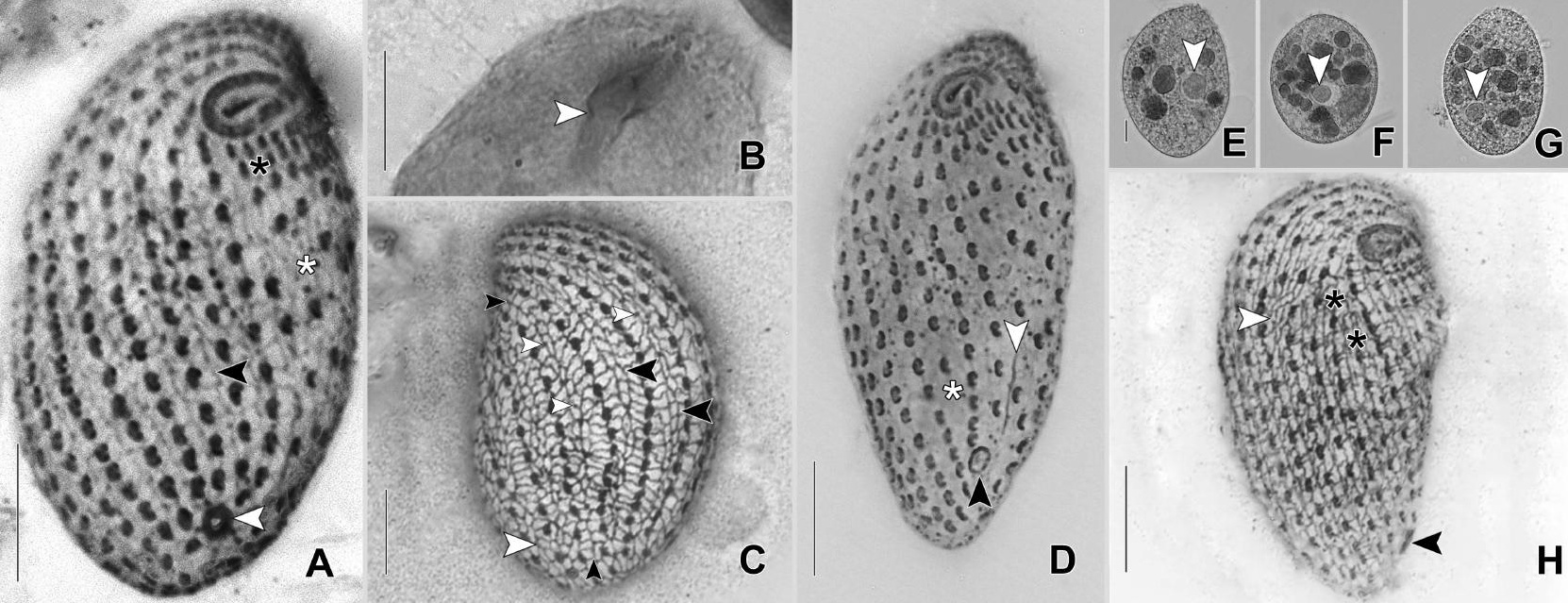




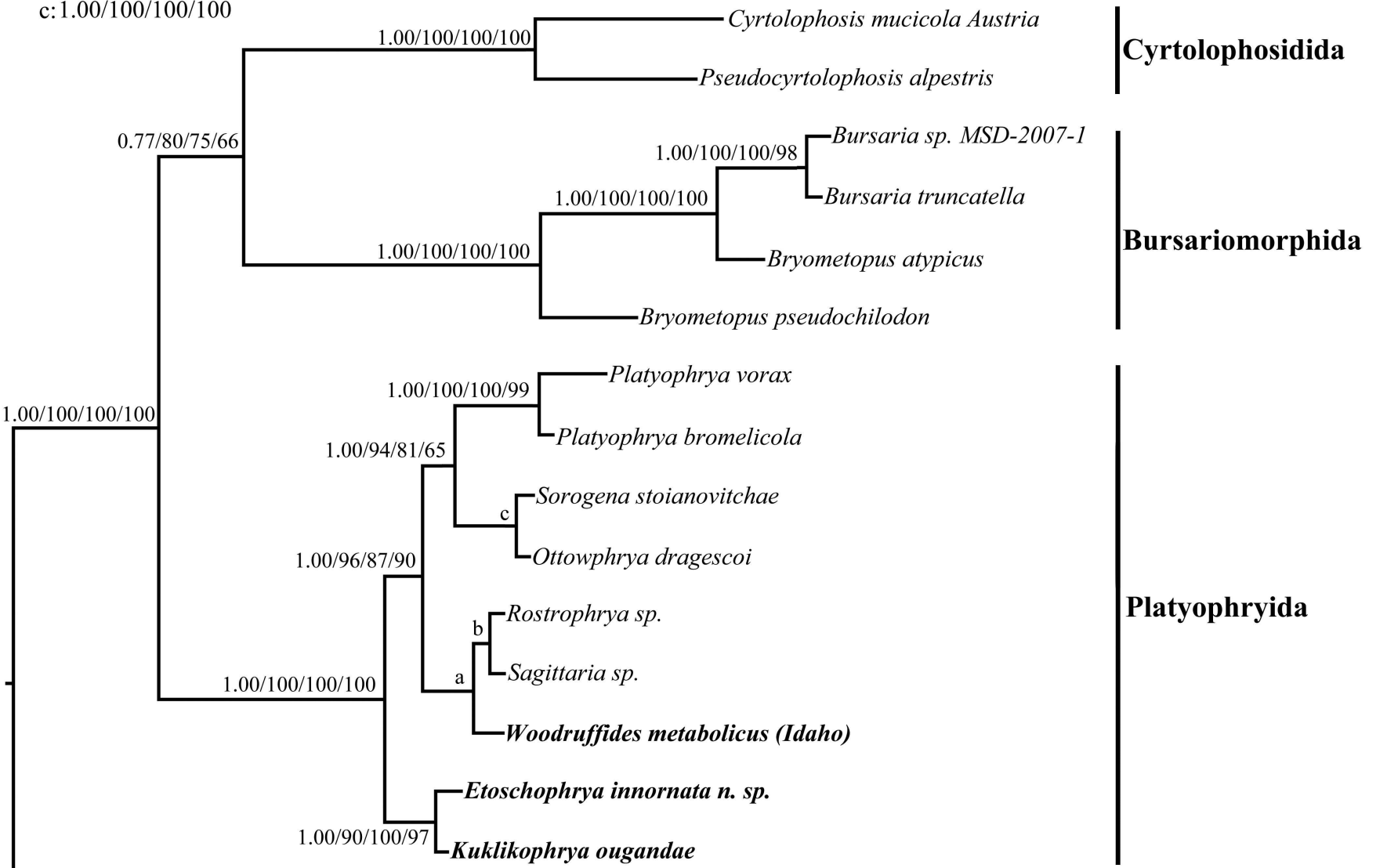

Cyrtolophosidida 
+ Reticulowoodruffia

$11-3 *$

$1-2,2-$

$3-2,7-$

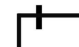

$100 / 1.00$

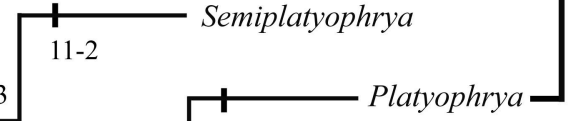

\section{Platyophryidae}

$-/ 0.63$

9-1*

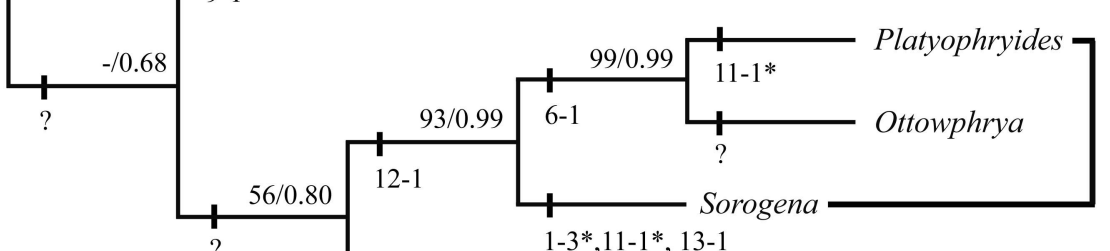

Sorogenidae

$1-3 *, 11-1 *, 13-1$

$1-3 *, 11-1 *$

Sagittaria | Sagittariidae

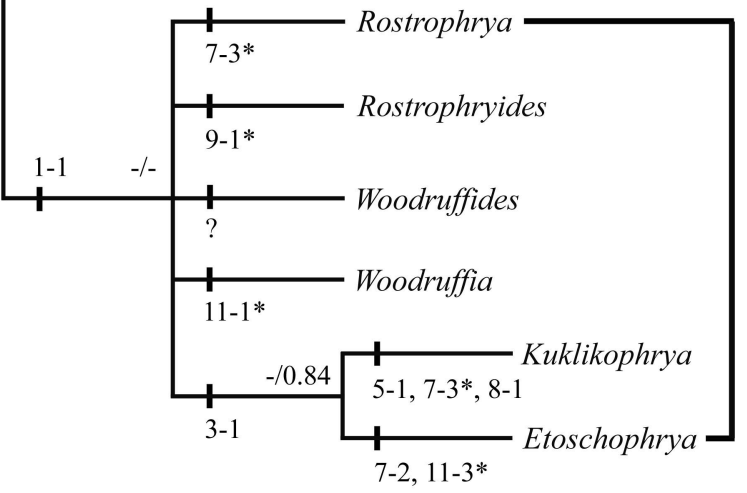

Woodruffiidae

Pseudocyrtolophosis 
